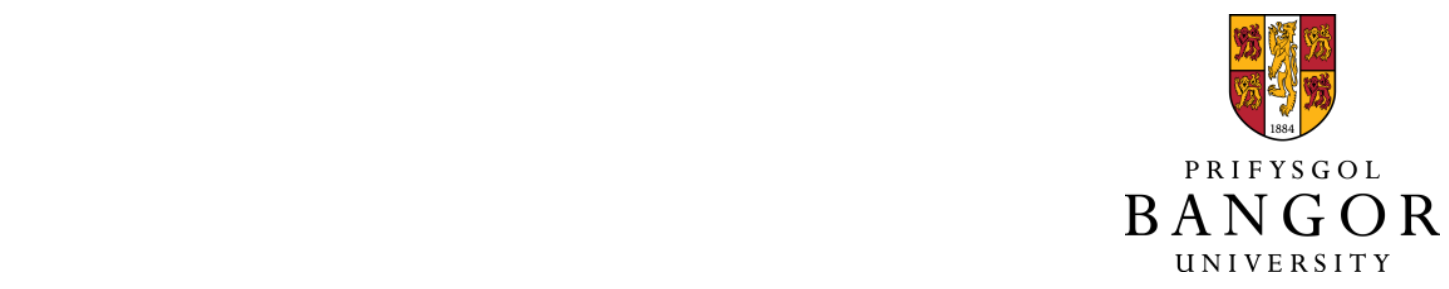

\title{
Regional-scale patterns in harbour porpoise occupancy of tidal stream environments
}

Waggitt, James; Dunn, H; Evans, Peter G. H.; Hiddink, Jan; Holmes, L J; Keen, E; Murcott, B D; Piano, Marco; Robins, Peter; Scott, B E; Bond, Jenny; Veneruso, Gemma

\section{ICES Journal of Marine Science}

DOI:

10.1093/icesjms/fsx164

Published: 01/03/2018

Peer reviewed version

Cyswllt i'r cyhoeddiad / Link to publication

Dyfyniad o'r fersiwn a gyhoeddwyd / Citation for published version (APA):

Waggitt, J., Dunn, H., Evans, P. G. H., Hiddink, J., Holmes, L. J., Keen, E., Murcott, B. D., Piano, M., Robins, P., Scott, B. E., Bond, J., \& Veneruso, G. (2018). Regional-scale patterns in harbour porpoise occupancy of tidal stream environments. ICES Journal of Marine Science, 701-710. https://doi.org/10.1093/icesjms/fsx164

\footnotetext{
Hawliau Cyffredinol / General rights

Copyright and moral rights for the publications made accessible in the public portal are retained by the authors and/or other copyright owners and it is a condition of accessing publications that users recognise and abide by the legal requirements associated with these rights.

- Users may download and print one copy of any publication from the public portal for the purpose of private study or research.

- You may not further distribute the material or use it for any profit-making activity or commercial gain

- You may freely distribute the URL identifying the publication in the public portal ?
}

Take down policy

If you believe that this document breaches copyright please contact us providing details, and we will remove access to the work immediately and investigate your claim. 


\title{
Regional-scale patterns in harbour porpoise occupancy of tidal stream environments
}

Waggitt J.J ${ }^{1}$; Dunn H. ${ }^{1}$; Evans P.G.H. ${ }^{1}, 3$; Hiddink J.G. ${ }^{1}$; Holmes L. ${ }^{1}$; Keen E. ${ }^{1}$; Murcott B. ${ }^{1}$; Piano M. ${ }^{2}$; Robins P. ${ }^{2}$; Scott B.E. ${ }^{4}$; Whitmore J. ${ }^{2}$; Veneruso G. ${ }^{2}$

${ }^{1}$ School of Ocean Sciences, Bangor University, Menai Bridge, Anglesey, LL59 5AB, UK

${ }^{2}$ Centre for Applied Marine Sciences, Bangor University, Menai Bridge, Anglesey LL59 5AB, UK

${ }^{3}$ Sea Watch Foundation, Ewyn Y Don, Bull Bay, Amlwch Anglesey LL68 9SD, UK

${ }^{4}$ Institute of Biological and Environmental Sciences, University of Aberdeen, Aberdeen AB24 2TZ, UK

\begin{abstract}
As harbour porpoises Phocoena phocoena are abundant within tidal stream environments, mitigating population-level impacts from tidal stream energy extraction is considered a conservation priority. An understanding of their spatial and temporal occupancy of these habitats at a regional-scale will help steer installations towards locations which maximize energy returns but reduce the potential for interactions with populations. This study quantifies and compares relationships between the presence of harbour porpoise and several hydrodynamic characteristics across four tidal stream environments in Anglesey, UK-a region that has been earmarked for extensive industrial development. Within sites $(0.57-$ $1.13 \mathrm{~km} 2)$, encounters with animals were concentrated in small areas $(<200 \mathrm{~m} 2)$ and increased during certain tidal states (ebb vs. flood). In sites showing relatively high maximum current speeds $\left(2.67-2.87 \mathrm{~ms}^{-1}\right)$, encounters were strongly associated with the emergence of shearlines. In sites with relatively low maximum current speeds (1.70-2.08 ms-1), encounters were more associated with areas of shallow water during peak current speeds. The overall probability of encounters was higher in low current sites. It is suggested that the likelihood of interactions could be reduced by restricting developments to sites with high maximum current speeds $(>2.5 \mathrm{~ms}-1)$, and placing turbines in areas of laminar currents therein. This study shows that a combination of local and regional hydrodynamic characteristics can partially explain variations in occupancy patterns across tidal-stream environments. However, it was found that such hydrodynamic characteristics could not comprehensively explain these occupancy patterns. Further studies into the biophysical mechanisms creating foraging opportunities within these habitats are needed to identify alternative explanatory variables that may have universal applications.
\end{abstract}

Keywords: cetacean, environmental impact assessment, foraging ecology, hydrodynamic model, marine renewable energy installations, marine spatial planning, shore-based surveys

Published in ICES Journal of Marine Science, March 2018, Volume 75, 701-710

\section{Introduction}

There is an increasing exploitation of marine resources for commercial and recreational activities, which could have negative impacts on cetaceans. Consequently, understanding spatial and temporal distribution has become increasingly important for conservation purposes (Evans and Anderwald, 2016). In particular, this understanding could help the environmentally 
responsible management of anthropogenic activities by; (i) predicting the distributions of vulnerable populations, and then (ii) constraining activities to times and locations which collectively reduce the likelihood of interactions (Waggitt and Scott, 2014).

The emerging tidal stream energy industry is an example of where environmentally responsible management is needed. Exploitable resources are found around headlands/islands and through narrow channels where currents accelerate (Lewis et al., 2015; Robins et al., 2015). These tidal stream environments attract harbour porpoise Phocoena phocoena (Benjamins et al., 2015) - a species that is considered vulnerable to negative impacts such as collisions with moving components of turbines (Wilson et al., 2007a) and displacement from foraging areas. Reducing the likelihood of interactions between harbour porpoise and installations could be seen as a conservation priority during industrial expansion. Studies investigating spatial and temporal occupancy patterns within individual sites $(<2 \mathrm{~km} 2)$ have shown encounters to increase during particular tidal states or areas (Benjamins et al., 2015). However, the tidal state and characteristics of the area associated with increased encounters differ among studies (Benjamins et al., 2015). Moreover, spatial and temporal occupancy patterns could differ greatly among neighbouring sites $<10 \mathrm{~km}$ apart (Gordon et al., 2011; Benjamins et al., 2016). As it cannot be assumed that occupancy patterns persist across regions (10-100 km2), selecting a suite of development sites and turbine locations which reduce the likelihood of interactions with animals is problematic. An ability to predict variations in occupancy patterns at a regionalscale would have an important role in mitigating negative impacts on populations (Waggitt et al., 2017).

Hydrodynamic characteristics influence occupancy patterns in tidal stream environments (Hunt et al., 1999; Benjamins et al., 2015). Harbour porpoises often aggregate in shear-lines found between fast laminar and slower eddying flows in the wake of headlands/islands (Johnston et al., 2005; Jones et al., 2014), where intense turbulence disorientate and/or break-up shoals of prey (Liao, 2007). Circular currents associated with shear-lines aggregate these shoals (Wolanski et al., 1988; Johnston and Read, 2007) and decrease searching time (Elliott et al., 2009), whereas relatively fast current speeds help to transport prey from surrounding waters (Zamon, 2001). Friction between these currents and the seabed in shallow areas also generate complex vertical currents characterized by standing waves and fine-scale turbulence, which further increase foraging efficiency (Hunt et al., 1998; Waggitt et al., 2016a). However, despite these advantages, animals may avoid areas of 
particularly strong or complex currents due to high swimming costs or prey-handling difficulties (Heath and Gilchrist, 2010; Waggitt et al., 2016b). Such avoidance could be particularly evident in animals exploiting prey on or near the seabed, due to the lengthy searches associated with capturing these items (Butler and Jones, 1997).

Local topography and the diurnal tidal cycle mean that hydrodynamic characteristics will differ spatially and temporally within sites. Regional topography also cause maximum current speeds, and the intensity of these hydrodynamic characteristics, to differ considerably among neighbouring sites (Milne et al., 2013). Consequently, tidal stream environments could have quite different hydrodynamic regimes despite their broader similarities. This study sought to explain spatial and temporal variations in occupancy patterns within and across tidal-stream environments within Anglesey, UK, using local and regional hydrodynamic characteristics. Local variations in hydrodynamic characteristics within sites were described using relative current speeds, current speed gradients (identifying shear-lines) and depth; regional variations in hydrodynamic characteristics among sites were described using maximum current speeds. The distribution of harbour porpoise was recorded using standardized shore-based surveys (Evans and Hammond, 2004) over 2 weeks in June 2016. These datasets were then combined to address three questions: (i) Are spatial and temporal occupancy patterns within sites explained by relationships with local hydrodynamic characteristics; (ii) can maximum current speed explain any variations in these relationships among sites; (iii) is the overall probability of encountering harbour porpoise correlated with maximum current speed?

\section{Methods}

\section{Study site and period}

Shore-based surveys were performed between 10 and 25 June 2016 at four sites in north Anglesey, UK: Point Lynas ( $\left.53^{\circ} 25.010^{\prime} \mathrm{N}, 004^{\circ} 17.158^{\prime} \mathrm{W}\right)$, Middle Mouse (532 $25.631^{\prime} \mathrm{N}$, $\left.004^{\circ} 26.152^{\prime} \mathrm{W}\right)$, Carmel Head (53 $\left.24.218^{\prime} \mathrm{N}, 004^{\circ} 34.415^{\prime} \mathrm{W}\right)$ and South Stack $\left(53^{\circ} 18.258^{\prime}\right.$ $\mathrm{N}, 004^{\circ} 41.602^{\prime} \mathrm{W}$ ) (Figure 1). Sites covered areas between 0.57 and $1.13 \mathrm{~km} 2$ (Supplementary Table S1). These four sites: (i) are characterized by current speeds exceeding $1.5 \mathrm{~ms}^{-1}$ during certain tidal states, making them suitable for tidal stream energy extraction (Robins et al., 2014); (ii) have different maximum current speeds, with values generally higher within western than eastern locations (Robins et al., 2014); (iii) have a relatively high number of encounters 
during summer months, based upon analyses of previous shore-based surveys (Evans et al., 2015); (iv) are spaced almost equidistantly across $\sim 40 \mathrm{~km}$ of the coastline (Figure 1).

\section{Shore-based surveys}

Shore-based surveys consisted of a series of visual scans using tripod mounted Opticron Marine-2 binoculars at seven times magnification. A total of 528 scans were performed: 125 at Point Lynas, 150 at Middle Mouse, 133 at Carmel Head and 120 at South Stack. Scans were undertaken at 15-min intervals during surveys that lasted between $30 \mathrm{~min}$ and $3 \mathrm{~h}$. Attempts were made to divide scans equally between ebb and flood tides. Although some biases occurred, a satisfactory amount of scans were performed in both flood and ebb tides at each site (Supplementary Table S1). In most cases, two people were present during each scan - one to perform the observations with the binoculars, and the other to record any sightings.

During scans, the distance and angle to sightings of harbour porpoise were recorded using binocular reticules and compass, respectively; this enabled their positions to be estimated. If the observer believed that the same animal was re-sighted several times during a scan, only their initial position was recorded. As the accuracy of this calculation is based upon counting the number of reticules between the sighting and the horizon, scans were also only performed when the position of the horizon could be accurately identified. The maximum range scanned at most sites was $\sim 1.5 \mathrm{~km}$ from the vantage point. However, at Point Lynas, where the vantage point was considerably lower than other sites, this range was constrained to $1 \mathrm{~km}$ due to the decreasing resolution of positions at larger ranges under these circumstances. For similar reasons, nearshore areas were also not covered (25-500 $\mathrm{m}$ from coastlines, depending upon the site) due to the increasing difficulty of measuring reticules from the horizon at shorter ranges. Despite these constraints, survey areas covered hydrodynamic features of interest within each site. Using these approaches, the spatial resolution of sightings was estimated to be $\sim 100 \mathrm{~m}$.

To spread observation intensity equally across the survey area, this area was divided into three zones (Figure 2). All areas within the three zones were visible throughout scans. In situations where zones were seemingly hidden from vantage points (e.g. Middle Mouse), shallow-sloping headlands enabled observers to view beyond these features. During scans, observers watched each zone for a defined time, which equated to $\sim 0.14 \mathrm{~km} 2$ scanned per minute. In total, survey areas were scanned for between $\sim 4$ and $9 \mathrm{~min}$, depending upon the study area of the site. Full details on the extent and duration of scans per site are provided in 
the Supplementary Tables S2 and S3. By standardizing observation effort among the aforementioned three zones, sightings were less likely to be spatially biased. As the detection of animals becomes more difficult in rougher sea surfaces, scans were only performed when the sea state was less than Beaufort scale 3 (Evans and Hammond, 2004). By limiting ranges to $1.5 \mathrm{~km}$ from the vantage point, using zones to focus observations, and only performing scans in good conditions, it was believed that spatial variations in detectability of animals associated with distance and sea surface characteristics should be negligible (Waggitt et al., 2014).

\section{Hydrodynamic model}

Hydrodynamic characteristics were quantified from a simulation model using the Telemac Modelling System (v7.1). The model domain encompassed the entire Irish Sea (50$56^{\circ} \mathrm{N}, 8-3^{\circ} \mathrm{W}$ ), and consisted of an unstructured finite-element mesh. The mesh resolution varied from $\sim 10 \mathrm{~km}$ at the model boundaries, to $50 \mathrm{~m}$ along the north Anglesey coastline. Simulations were based on Admiralty Digimap bathymetry data (EDINA, 2008), with depth values corrected to represent mean sea-level. Within north Anglesey, the water column remains well-mixed, producing vertically homogeneous current speeds above the bottom boundary layer (Piano et al., 2015). Therefore, the simulation model was performed in depth-averaged mode (Telemac-2D), which provided a good approximation of flow characteristics across sites. Further details on the performance and validation of the simulation model are provided in Piano et al.(2015) and Robins et al. (2014).

\section{Data processing}

The presence and absence of harbour porpoise was quantified using an orthogonal grid at $100 \mathrm{~m}$ and $15 \mathrm{~min}$ resolution. The first two explanatory variables, current speed (Spd: $\mathrm{ms}-1)$ and water depth (Depth: m), were extracted from simulation models and interpolated onto the same orthogonal grid using a kriging approach. The third explanatory variable, current speed gradient $(S p d G$ : $\mathrm{ms}-1)$, was then calculated from $\mathrm{Spd}$ values using a terrain ruggedness index (Wilson et al., 2007b). SpdG identified the shear-lines found between fast laminar and slower eddying horizontal currents in the wake of headlands and islands. The final explanatory variable, maximum current speed MaxSpd (ms-1) was calculated from Spd values for each site, using the maximum value across a spring-neap tidal cycle. Calculations of MaxSpd also included values up to $500 \mathrm{~m}$ surrounding the survey areas, to quantify general conditions at each site. This approach provided concurrent information on the presence/absence of harbour 
porpoise and hydrodynamic characteristics for each cell per scan, resulting in a sample size of 67809 for statistical analyses.

\section{Tidal terminology}

Throughout the results and discussion sections, tidal states will be defined as follows: (i) "high tide" and "low tide" identify times of highest and lowest Depth values, respectively; (iii) "flood tide" identifies any time between low tide and high tide, whereas "ebb tide" identifies any time between high tide and low tide; (iii) "high-" and "low-slack tide" identify times when $S p d$ values are at their lowest, with the former and latter indicating that this time is closer to high tide and low tide, respectively (Waggitt et al., 2016b).

\section{Analysis}

The probability of detecting a harbour porpoise in a cell as a function of Spd, SpdG Depth, and MaxSpd was modelled using generalized linear models (GLMs) with a binomial distribution. Statistical analysis was performed using 'R' (version 3.0.2, R Development Core Team, 2013). GLM were preferred over general additive models (GAMs) (Wood, 2006) because statistical aims: (i) concerned the identification of broad associations with hydrodynamic features (e.g. fast vs. slow currents, shear-lines, shallow vs. deep water) rather than the quantification of functional responses to $S p d, S p d G$, Depth or MaxSpd gradients, and (ii) involved direct comparisons of relationships and effect sizes among explanatory variables and sites, which are facilitated by the provision of slope estimates. Exploratory analyses using ecologically interpretable GAMs (i.e. the number of knots were constrained to 3, Waggitt et al., 2016b) revealed almost linear relationships between detections and hydrodynamic characteristics, indicating that this selection was appropriate. Model residuals showed little evidence of extreme temporal or spatial autocorrelation (Supplementary Figures S1 and S2). Therefore, more advanced statistical approaches accounting for temporal and spatial autocorrelation, including general estimation equations and generalized linear mixed effect models, were deemed unnecessary (Zuur et al., 2009).

Sea state (Beaufort scale) was included as an explanatory variable to account for possible decreases in animal detectability during poor weather (Evans and Hammond, 2004). Although there could also be decreases in areas furthest away from the observer (Buckland et al., 2001), distance to the vantage point was not included as an explanatory variable. This was 
due to collinearity between distance and several hydrodynamic characteristics of interest. However, because such collinearity was apparent at the onset of this study, surveys were designed to overcome issues with distance from the vantage point (see "Shore-based surveys" Section).

All hydrodynamic characteristics were modelled as continuous explanatory variables. Spd, SpdG, Depth, and were modelled as interaction terms with MaxSpd, to test whether any differences in relationships in the former among sites could be explained by the latter. As analysis was interested in identifying occupancy patterns within sites using relative hydrodynamic characteristics, local hydrodynamic characteristics ( $S p d, S p d G$, and Depth) were standardized per site by mean centering values. As absolute hydrodynamic characteristics could be important in interpreting differences in occupancy patterns among sites, regional hydrodynamic characteristics (MaxSpd) were not standardized.

Backwards model selection based on p-values was performed (Zuur et al., 2009). Fitted lines with standard errors were calculated for each relationship, using slope estimates. In these calculations, the hydrodynamic characteristic of interest was varied between its minimum and maximum value, whilst other hydrodynamic characteristics were held at their mean values. Sea state was held at 0 across all calculations, to represent optimal conditions. The effect size of relationships was quantified using proportional differences $(\mathrm{Pd})$. Pd represented the absolute difference between the maximum and minimum predicted values divided by the minimum predicted value, quantifying the relative influence of each hydrodynamic characteristic on the probability of detecting a harbour porpoise.

\section{Results}

\section{Hydrodynamic characteristics}

Spatial and temporal variations in $S p d, S p d G$, and Depth for each site are shown in Figures 3-5. As expected from prior-knowledge, MaxSpd values differed greatly among sites, with western locations having considerably higher values than eastern locations (Point Lynas $=1.70 \mathrm{~ms}^{-1}$; Middle Mouse $=2.08 \mathrm{~ms}^{-1}$; Carmel Head $=2.67 \mathrm{~ms}-1$; South Stack $=$ $\left.2.87 \mathrm{~ms}^{-1}\right)$.

\section{Harbour porpoise sightings}


Spatial and temporal variations in the probability of encountering an animal in a cell for each site are shown in Figures 6 and 7. Absolute sightings rates per site and tidal state are shown in Supplementary Table S4. The probability of encountering an animal in a cell decreased moving from Point Lynas (0.023), Middle Mouse (0.004), Carmel Head (0.003) to South Stack (0.002). Therefore, probabilities were lower in western than eastern sites. There were clear spatial and temporal variations in the distribution of sightings within each site, although these occupancy patterns differed among sites. Sightings rates increased during flood tides at Point Lynas, ebb tides at Carmel Head and South Stack, and around high tide at Middle Mouse (Figure 6). Sightings occurred throughout the survey area across sites, but peaked within relatively small areas (100-200 m2) which were generally found $<600 \mathrm{~m}$ from the coastline (Figure 7).

Fitted lines illustrating relationships between the probability of encountering animals and hydrodynamic characteristics are shown in Figure 8. Probabilities showed consistently positive and weak relationships with $S p d$ across sites $(\mathrm{Pd}=0.80$ at Point Lynas; $\mathrm{Pd}=0.97$ at Middle Mouse; $\mathrm{Pd}=0.78$ at Carmel Head; $\mathrm{Pd}=0.88$ at South Stack). In contrast, probabilities showed variable relationships with $\operatorname{SpdG}$ and Depth; however, MaxSpd explained this variability. Relationships with $S p d G$ were weak and negative in the lowest current site $(\mathrm{Pd}=$ 0.84 at Point Lynas), but moderate/strong and positive in the higher current sites $(\mathrm{Pd}=2.37$ at Middle Mouse; $\mathrm{Pd}=179.98$ at Carmel Head; $\mathrm{Pd}=159.17$ at South Stack). Relationships with Depth were moderate/strong and negative at lower current sites $(\mathrm{Pd}=6.50$ at Point Lynas; $\mathrm{Pd}$ $=1.42$ at Middle Mouse) but moderate/strong and positive relationships in higher current sites $(\mathrm{Pd}=1.27$ at Carmel Head; $\mathrm{Pd}=4.73$ at South Stack). A negative relationship was seen between probabilities and MaxSpd, with predicted probabilities of encountering animals being 27.59 times higher in the lowest than the highest current site. There was also a negative relationship between probabilities and Sea State.

Relationships with hydrodynamic characteristics explain occupancy patterns convincingly at Carmel Head and South Stack; increased sightings during ebb tides (Figure 6) near headlands (Figure 7) coincided with times and areas of high Spd/high SpdG/higher Depth (Figures 3-5). Similar conclusions were made at Middle Mouse; increased sightings around high tide (Figure 6) near the headland (Figure 7) coincided with times and areas of high Spd/high SpdG/low Depth (Figures 3-5). In contrast, these relationships cannot explain occupancy patterns as well at Point Lynas; whilst increased sightings near the headland (Figure 
7) coincided with areas of high $S p d /$ low Depth, increases during flood tides did not coincide with times of high Spd/low SpdG/low Depth (Figures 3-5).

\section{Discussion}

This study sought to identify and explain harbour porpoise occupancy patterns within and across four tidal-stream environments in Anglesey, UK. There were three main findings: (i) spatial and temporal variations in the probability of encountering animals within sites were partially explained by relationships with $S p d, S p d G$, and Depth; (ii) relationships with these hydrodynamic characteristics differed among sites, although these differences were correlated to variations in MaxSpd; and (iii) the overall probability of encounters with harbour porpoise were higher in sites with lower MaxSpd. In combination, these findings show that differences in occupancy patterns among tidal stream environments can be partially explained by local and regional hydrodynamic characteristics. The possible biophysical mechanisms underlying these findings, and their implications for the environmentally sustainable management of the tidal stream energy industry, are discussed below.

\section{Biophysical mechanisms}

Relationships with hydrodynamic characteristics explained occupancy patterns reasonably well at Middle Mouse, Carmel Head and South Stack. In contrast, they were unable to explain increased encounters during flood tides at Point Lynas. Interactions between currents and particularly complex bathymetry (G. Veneruso, pers. comm.) create several strong hydrodynamic features at Point Lynas. As detailed bathymetry was not available across sites, these additional hydrodynamic features were not detected by the simulation model used here. The identification and quantification of these features would probably help explain occupancy patterns better at this site. These slight discrepancies demonstrate the need to comprehensively understand local processes when fully explaining occupancy patterns (Evans, 1990). Such an understanding could be obtained from higher resolution and 3D simulation models (Waggitt et al., 2016a) and/or in situ measurements (Hunt et al., 1998; Jones et al., 2014).

Encounters with animals at higher current sites became strongly associated with shearlines. In contrast, those at lower current sites became more closely associated with areas of shallow water during peak current speeds. These differences could reflect variations in prey vulnerability. Although measures of shear-lines were not necessarily greater in high current 
sites, turbulent structures within these features are probably more intense within these sites (Milne et al., 2013). Consequently, shear-lines may become more profitable in high current sites because turbulent structures within these features are better at disorientating and breakingup shoals of fish (Liao, 2007). Such differences could also reflect differences in bathymetric characteristics across sites. Higher levels of seabed erosion and lower levels of sediment deposition within high current sites (Robins et al., 2014) are likely to prevent shallow water occurring immediately alongside headlands. Indeed, such areas were absent at Carmel Head and South Stack, despite their broadly similar topographies to Point Lynas and Middle Mouse. Therefore, it is suggested that prey exploitability and physical structure collectively explain the differences in associations across maximum current speed gradients.

The higher probabilities of encounters in low current sites seem to relate to higher numbers of sightings, rather than more consistent sightings across tidal states. This may be linked to the particularly ephemeral distribution of shear-lines in time and space, meaning that fewer foraging opportunities arise in high current sites. It may also occur through aggregations of mother-calf and juvenile groups, avoiding high current sites due to increased swimming costs (Read and Hohn, 1995). However, results showed that the probabilities of detecting animals were substantially higher at Point Lynas than other sites. Therefore, variances in maximum current speeds among sites cannot fully explain trends. This finding could again be linked to an undetected yet influential hydrodynamic feature at this site, increasing the number of foraging opportunities. A scale-dependent response to current speeds was also demonstrated; at a regional-scale animals were encountered more in low current sites, yet sightings increased when and where currents speed peaked in these sites. These differences demonstrate the importance of considering spatial and temporal scale when interpreting and extrapolating relationships between animals and environmental variables (Scales et al., 2017).

\section{Explanatory variables}

Although the explanatory variables used within analyses were based on associations from previous studies (Benjamins et al., 2015), they were unable to comprehensively explain occupancy patterns across sites. Therefore, explanatory variables with universal applications within tidal stream environments have yet to be identified. Most hydrodynamic features associated with foraging activities within these habitats are characterized by complex and intense turbulent structures (Benjamins et al., 2015). Moreover, as discussed previously, some variations in occupancy patterns across sites may be explained through the intensity and 
complexity of turbulence. Future studies should aim to identify whether and which measure represents a suitable explanatory variable. In situ and simultaneous quantification of turbulence and predator-prey interactions represent a suitable approach (Williamson et al., 2015, 2017; Fraser et al., 2017). However, their subsequent application depends on the continued development of simulation models capable of quantifying high-resolution turbulence across regions (Togneri et al., 2017).

\section{Other species}

Whereas harbour porpoise are perhaps most associated with tidal stream environments, other cetacean species also use these habitats; in particular, bottlenose dolphin Tursiops truncatus and minke whale Balaenoptera acutorostrata (Benjamins et al., 2015). The foraging techniques and/or dietary preferences of these species are variable (Evans, 2008), meaning that they presumably exploit these habitats differently to harbour porpoise. Therefore, it seems unlikely that the associations with hydrodynamic characteristics shown in this study are applicable for bottlenose dolphin and minke whale.

\section{Annual and seasonal variations}

Although harbour porpoise feed primarily on demersal and shoaling fish within northwest Europe (Santos and Pierce, 2003), seasonal and annual changes in prey communities can influence foraging strategies (Wanless et al., 1998; Watanuki et al., 2004; Garthe et al., 2007). Shore-based surveys were constrained to a 2-week period during June 2016. Moreover, whilst temporal variations in diet have been documented elsewhere (Santos et al., 2004), these variations have not been documented within the study region. Without covering multiple seasons and years, or understanding temporal variations in diet, this study cannot infer consistent associations. However, shore-based surveys spanning multiple seasons and years in tidal stream environments have revealed consistent associations with hydrodynamic features (Jones et al., 2014). Therefore, the possibility of consistent associations within the study region seems realistic, although additional surveys in different seasons and months would be needed to investigate these possibilities.

\section{Tidal stream turbines}


Extensive areas around north Anglesey have been leased from the Crown Estate for the extraction of tidal stream energy (Roche et al., 2016). This region is known to support nationally important populations of harbour porpoise (Baines and Evans, 2012). At this predevelopment stage, the environmentally responsible management of this sector would benefit from predicting occupancy patterns of harbour porpoise across and within these areas, identifying a suite of development sites and turbine locations which reduce the likelihood of interactions (Davies et al., 2014). Occupancy patterns could have been explained further through the inclusion of additional explanatory variables and/or species distribution modelling using GAMs (Elith and Leathwick, 2009). However, the fine-resolution and 3D variables needed for these approaches are unlikely to be available across regions, meaning that extrapolation of occupancy patterns across sites is problematic. By focussing on explanatory variables which can be quickly quantified across regions at the present time, this study provides a pragmatic framework in which suitable development sites and turbine locations can be selected.

It is suggested that selecting sites with the highest maximum current speeds, and installing devices in laminar currents within these sites, could help to minimize the likelihood of interactions. In practice, these suggestions may not require compromise from the industry; energy extraction is more efficient in locations with the highest maximum current speeds (Robins et al., 2015) whilst placing devices within shear-lines is considered undesirable due to inefficient energy extraction and increased stresses on components (Myers and Bahaj, 2010). However, installations will have substantial impacts on local hydrodynamic regimes, particularly through the creation of complex currents in the immediate wake of devices (Chen et al., 2015). The strong associations with shear-lines highlights a possibility of harbour porpoise being attracted to installations, and post-installation monitoring should focus on this possibility. This possibility highlights the importance of not only describing, but understanding, occupancy patterns during risk assessments (Scott et al., 2014).

\section{Supplementary data}

Supplementary material is available at the ICESJMS online version of the article.

\section{Acknowledgements}


J.J Waggitt, P.G.H. Evans, and J.G. Hiddink are supported through the Marine Ecosystems Research Programme (MERP: NE/L003201/1) which is funded by NERC/DEFRA. M. Piano, P.E. Robins, J. Whitmore, and G. Veneruso are supported through the Sustainable Expansion of the Applied Coastal and Marine Sectors (SEACAMS2) research project (Grant Number: 80366) part funded by the European Regional Development Fund (ERDF) through the Welsh European Funding Office (WEFO) and also the Higher Education Funding Council for Wales (HEFCW). Simulation models were made possible by High Performance Computing (HPC) Wales (a collaboration between Welsh Universities, the Welsh Government and Fujitsu), the British Oceanographic Data Centre (BODC), the UK Hydrographic Office (UKHO), and the EDINA Marine Digimap Service. We wish to thank three anonymous reviewers and Kees Camphuysen for their constructive comments on earlier versions of this article.

\section{References}

Baines, M. E., and Evans, P. G. H. 2012. Atlas of the marine mammals of Wales. CCW Monitoring Report No. 68. 2nd edition. 139 pp.

Barton, K. A. 2014. MuMIn: Multi-model inference. R package version 1.10.0.

Bates, D., Maechler, M., Bolker, B. M., and Walker, S. 2013. lme4: Linear mixed-effects models using Eigen and S4. R package version 1.0-5.

Benjamins, S., Dale, A., Hastie, G., Lea, M., Scott, B. E., Waggitt, J. J., and Wilson, B. 2015. Confusion reigns? A review of marine megafauna interactions with energetic tidal features. Oceanography and Marine Biology: An Annual Review, 53: 1-54.

Benjamins, S., van Geel, N., Hastie, G., Elliott, J., and Wilson, B. 2016. Harbour porpoise distribution can vary at small spatiotemporal scales in energetic habitats. Deep Sea Research Part II: Topical Studies in Oceanography.

Bjørge, A. 2001. How Persistent are Marine Mammal Habitats in an Ocean of Variability? In Marine Mammals: Biology and Conservation, pp. 63-91. Ed. by P. G. H. Evans and J. A. Raga. Boston, MA.

Burnham, K. P., and Anderson, D. R. 2002. Model selection and multimodel inference. Springer, New York, UK. 
Butler, P. J., and Jones, D. R. 1997. Physiology of diving of birds and mammals. Physiological Reviews, 77: 837-899.

Chen, Y., Lin, B., Lin, J., and Wang, S. 2015. Effects of stream turbine array configuration on tidal current energy extraction near an island. Computers \& Geosciences, 77: 20-28.

Davies, I. M., Watret, R., and Gubbins, M. 2014. Spatial planning for sustainable marine renewable energy developments in Scotland. Ocean and Coastal Management, 99: 72-81.

de Boer, M. N., Simmonds, M. P., Reijnders, P. J. H., and Aarts, G. 2014. The Influence of Topographic and Dynamic Cyclic Variables on the Distribution of Small Cetaceans in a Shallow Coastal System. PLoS ONE, 1: 10.1371/journal.pone.0086331.

EDINA. 2008. Marine Digimap Service.

Elliott, K. H., Bull, R., Gaston, A. J., and Davoren, G. K. 2009. Underwater and above-water search patterns of an Arctic seabird: reduced searching at small spatiotemporal scales. Behavioural Ecology and Sociobiology, 63: 1773-1785.

Evans, P. 1990. European cetaceans and seabirds in an oceanographic context. Lutra, 33: 95125.

Evans, P. G. H., and Anderwald, P. 2016. Addressing human pressures upon marine mammals: a European and global perspective. Journal of the Marine Biological Association of the United Kingdom, 96: 779-781.

Evans, P., and Hammond, P. 2004. Monitoring cetaceans in European waters. Mammal Review, 34: 131-156.

Evans, P., Pierce, G., Veneruso, G., Weir, C., Gibas, D., Anderwald, P., and Santos, M. 2015. Analysis of long-term effort-related land-based observations to identify whether coastal areas of harbour porpoise and bottlenose dolphin have persistent high occurrence and abundance. JNCC Report No 543.

Fox, J., and Weisberg, S. 2011. An R Companion to Applied Regression. Sage, California, 
USA.

Garthe, S., Montevecchi, W. A., Chapdelaine, G., Rail, J. F., and Hedd, A. 2007. Contrasting foraging tactics by northern gannets (Sula bassana) breeding in different oceanographic domains with different prey fields. Marine Biology, 151: 687-694.

Gordon, J., Thompson, D., Leaper, R., Pierpoint, C., Calderan, S., Macaulay, J., and Gordon, T. 2011. Phase 2 - Studies of Marine Mammals in Welsh High Tidal Waters. A report to the Welsh Assembly Government.

Heath, J. P., and Gilchrist, H. G. 2010. When foraging becomes unprofitable: energetics of diving in tidal currents by common eiders wintering in the Arctic. Marine Ecology Progress Series, 403: 279-290.

Hunt, G. L., Mehlum, F., Russell, R. W., Irons, D., Decker, M. B., and Becker, P. H. 1999. Physical processes, prey abundance, and the foraging ecology of seabirds. In International Ornithological Congress, pp. 2040-2056.

Hunt, G. L., Russell, R. W., Coyle, K. O., and Weingartner, T. J. 1998. Comparative foraging ecology of planktivorous auklets in relation to ocean physics and prey availability. Marine Ecology Progress Series, 167: 241-259.

Isojunno, S., Matthiopoulos, J., and Evans, P. G. H. 2012. Harbour porpoise habitat preferences: robust spatio-temporal inferences from opportunistic data. Marine Ecology Progress Series, 448: 155-170.

Johnston, D. W., and Read, A. J. 2007. Flow-field observations of a tidally driven island wake used by marine mammals in the Bay of Fundy, Canada. Fisheries Oceanography, 16: 422435. Blackwell Publishing Ltd.

Johnston, D. W., Westgate, A. J., and Read, A. J. 2005. Effects of fine-scale oceanographic features on the distribution and movements of harbour porpoises Phocoena phocoena in the Bay of Fundy. Marine Ecology Progress Series, 295: 279-293. 
Jones, A. R., Hosegood, P., Wynn, R. B., De Boer, M. N., Butler-Cowdry, S., and Embling, C. B. 2014. Fine-scale hydrodynamics influence the spatio-temporal distribution of harbour porpoises at a coastal hotspot. Progress in Oceanography, 128: 30-48.

Lewis, M. J., Neil, S. P., Robins, P. E., and Hashemi, M. R. 2015. Resource assessment for future generations of tidal-stream energy arrays. Energy, 83: 403-415.

Liao, J. C. 2007. A review of fish swimming mechanics and behaviour in altered flows. Philosophical Transactions of the Royal Society B: Biological Sciences, 362: 1973-1993.

Milne, I. A., Sharma, R. N., Flay, R. G. J., and Bickerton, S. 2013. Characteristics of the turbulence in the flow at a tidal stream power site. Philosophical Transactions of the Royal Society A: Mathematical, Physical and Engineering Sciences, 371: 20120196.

Myers, L. E., and Bahaj, A. S. 2010. Experimental analysis of the flow field around horizontal axis tidal turbines by use of scale mesh disk rotor simulators. Ocean Engineering, 37: 218227.

Piano, M., Ward, S., Robins, P., Neill, S., Lewis, M., Davies, A. G., Powell, B., et al. 2015. Characterizing the tidal energy resource of the West Anglesey Demonstration Zone (UK), using Telemac-2D and field observations. In Proceedings of the XXII Telemac \& Mascaret Users Conference.

Pierpoint, C. 2008. Harbour porpoise (Phocoena phocoena) foraging strategy at a high energy, near-shore site in south-west Wales, UK. Journal of the Marine Biological Association of the United Kingdom, 88: 1167-1173.

Read, A. J., and Hohn, A. A. 1995. Life in the fast lane : the life history of harbor porpoises from the Gulf of Maine. Marine Mammal Science, 11: 423-440.

Redfern, J., Ferguson, M., Becker, E., Hyrenbach, K., Good, C., Barlow, J., Kaschner, K., et al. 2006. Techniques for cetacean-habitat modeling. Marine Ecology Progress Series, 310: 271-295. 
Robins, P. E., Neill, S. P., and Lewis, M. J. 2014. Impact of tidal-stream arrays in relation to the natural variability of sedimentary processes. Renewable Energy, 72: 311-321.

Robins, P. E., Neill, S. P., Lewis, M. J., and Ward, S. L. 2015. Characterising the spatial and temporal variability of the tidal-stream energy resource over the northwest European shelf seas. Applied Energy, 147: 510-522.

Roche, R. C., Walker-Springett, K., Robins, P. E., Jones, J., Veneruso, G., Whitton, T. A., Piano, M., et al. 2016. Research priorities for assessing potential impacts of emerging marine renewable energy technologies: Insights from developments in Wales (UK). Renewable Energy, 99: 1327-1341.

Santos, M., and Pierce, G. 2003. The diet of harbour porpoise (Phocoena phocoena) in the Northeast Atlantic. Oceanography and Marine Biology: An Annual Review, 41: 355-390.

Scales, K. L., Hazen, E. L., Jacox, M., Edwards, C. A., Boustany, A. M., Oliver, M., and Bograd, S. J. 2017. Scale of inference: on the sensitivity of habitat models for wideranging marine predators to the resolution of environmental data. Ecography, 40: 210220. Blackwell Publishing Ltd.

Scott, B. E., Langton, R., Philpott, E., and Waggitt, J. J. 2014. Seabirds and marine renewables: Are we asking the right questions? In Humanity and the Seas: Marine Renewable Energy and Environmental Interactions, pp. 81-92. Ed. by M. A. Shields and A. I. L. Payne. Springer, London, UK.

Teilmann, J., Larsen, F., and Desportes, G. 2007. Time allocation and diving behaviour of harbour porpoises (Phocoena phocoena) in Danish waters. Journal of Cetacean Research \& Management, 9: 201-210.

Torres, R., and Uncles, R. J. 2011. Modelling of Estuarine and Coastal Waters. In Treatise on Estuarine and Coastal Science, pp. 395-427. Ed. by E. Wolanski and D. S. McLusky. Academic Press, Waltham, UK. 
Waggitt, J. J., Bell, P. S., and Scott, B. E. 2014. An evaluation of the use of shore-based surveys for estimating spatial overlap between deep-diving seabirds and tidal stream turbines. International Journal of Marine Energy, 8: 36-49.

Waggitt, J. J., Cazenave, P., Torres, R., Williamson, B. J., and Scott, B. E. 2016a. Quantifying pursuit-diving seabirds use of fine-scale physical features in tidal stream environments. Journal of Applied Ecology, 53: 1653-1666.

Waggitt, J. J., Cazenave, P., Torres, R., Williamson, B. J., and Scott, B. E. 2016b. Predictable hydrodynamic conditions explain temporal variations in the density of benthic foraging seabirds in a tidal stream environment. ICES Journal of Marine Science, 73: 2677-2686. Waggitt, J. J., Robbins, A. M. C., Wade, H. M., Masden, E. A., Furness, R. W., Jackson, A. C., and Scott, B. E. 2017. Comparative studies reveal variability in the use of tidal stream environments by seabirds. Marine Policy.

Waggitt, J. J., and Scott, B. E. 2014. Using a spatial overlap approach to estimate the risk of collisions between deep diving seabirds and tidal stream turbines: a review of potential methods and approaches. Marine Policy, 44: 90-97.

Wanless, S., Gremillet, D., and Harris, M. P. 1998. Foraging Activity and Performance of Shags Phalacrocorax aristotelis in Relation to Environmental Characteristics. Journal of Avian Biology, 29: 49-54.

Watanuki, Y., Ishikawa, K., Takahashi, A., and Kato, A. 2004. Foraging behavior of a generalist marine top predator, Japanese cormorants (Phalacrocorax filamentosus), in years of demersal versus epipelagic prey. Marine Biology, 145: 427-434.

Wilson, B., Batty, R. S., Daunt, F., and Carter, C. 2007a. Collision risks between marine renewable energy devices and mammals, fish and diving birds. Scottish Association of Marine Science report to the Scottish Executive.

Wilson, M. F. J., O’Connell, B., Brown, C., Guinan, J. C., and Grehan, A. J. 2007b. Multiscale 
Terrain Analysis of Multibeam Bathymetry Data for Habitat Mapping on the Continental Slope. Marine Geodesy, 30: 3-35.

Wolanski, E., Drew, E., Abel, K. M., and O’Brian, J. 1988. Tidal jets, nutrient upwelling and their influence on the productivity of the alga Halimeeda in the ribbon reefs, Great Barrier Reef. Estuarine, Coastal and Shelf Science, 26: 169-201.

Zamon, J. E. 2001. Seal predation on salmon and forage fish schools as a function of tidal currents in the San Juan Islands, Washington, USA. Fisheries Oceanography, 10: 353366. Blackwell Science Ltd. 


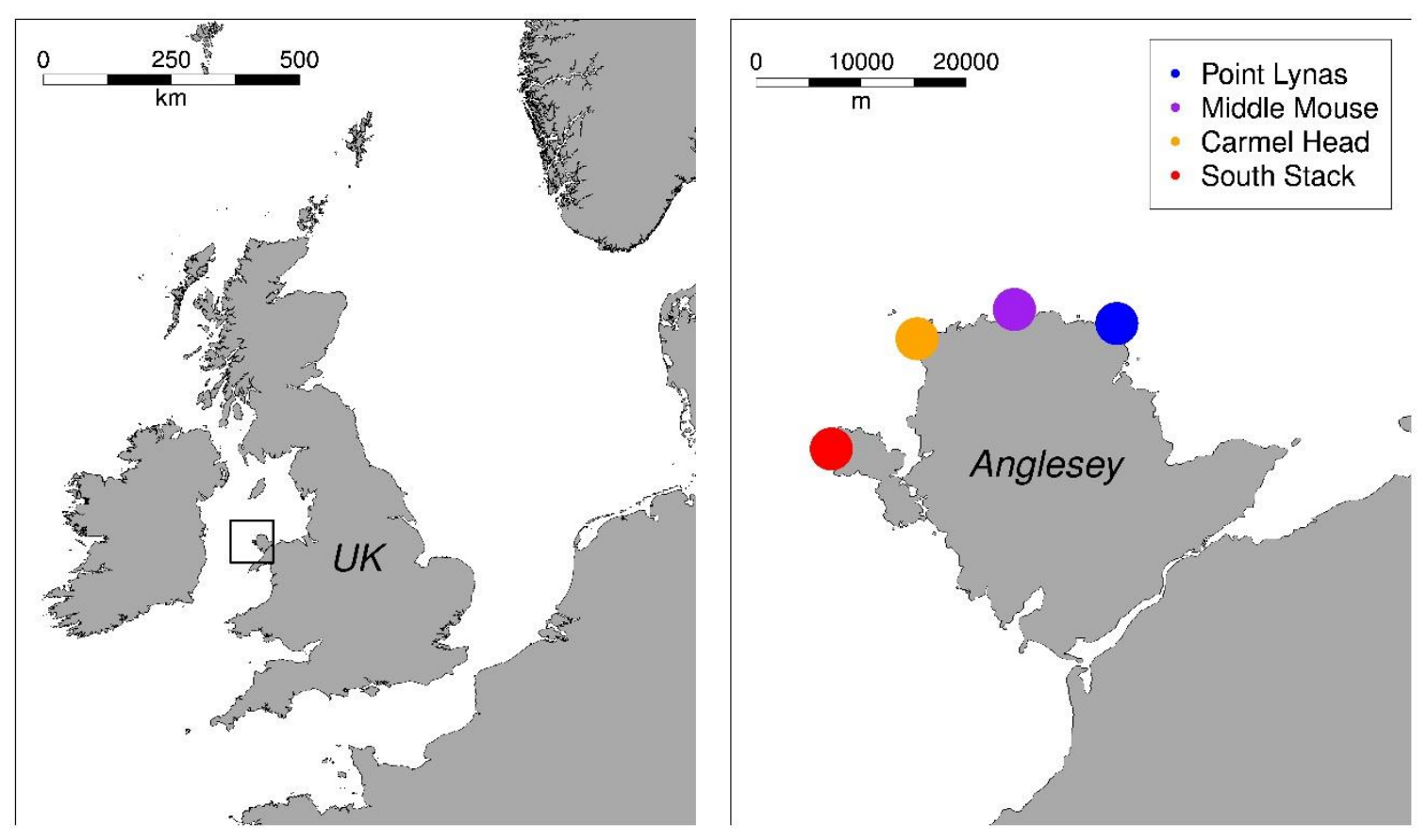

Figure 1: The locations of the four sites used for shore-based surveys between the $10^{\text {th }}$ and $24^{\text {th }}$ June 2016 in Anglesey, UK. The location of Anglesey in the UK is shown by a black box. 

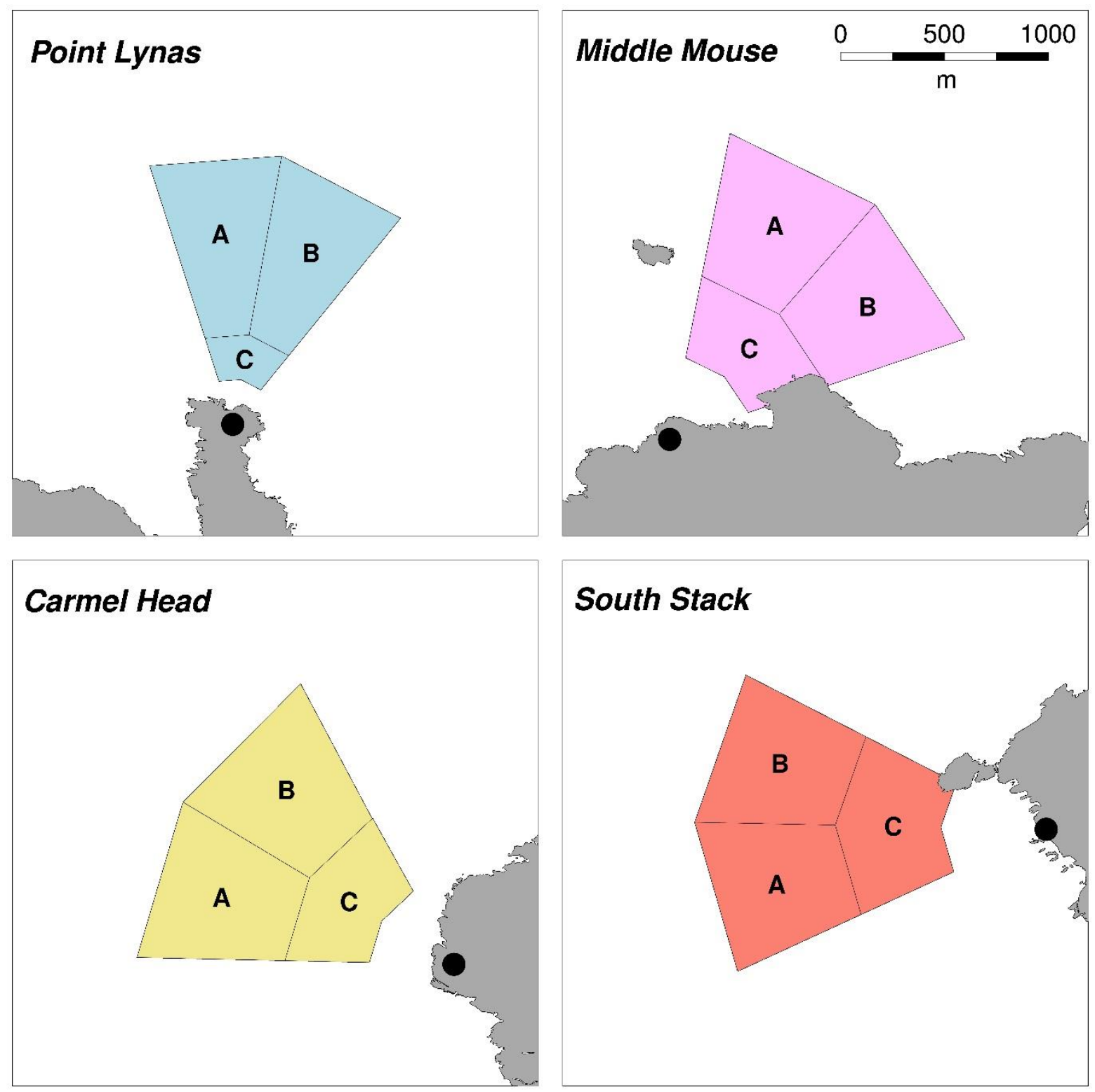

\section{South Stack}

Figure 2: The zones used to divide and quantify observation effort in shore-based surveys between the $10^{\text {th }}$ and $24^{\text {th }}$ June 2016 in Anglesey, UK. Black points represent the locations of vantage points. 

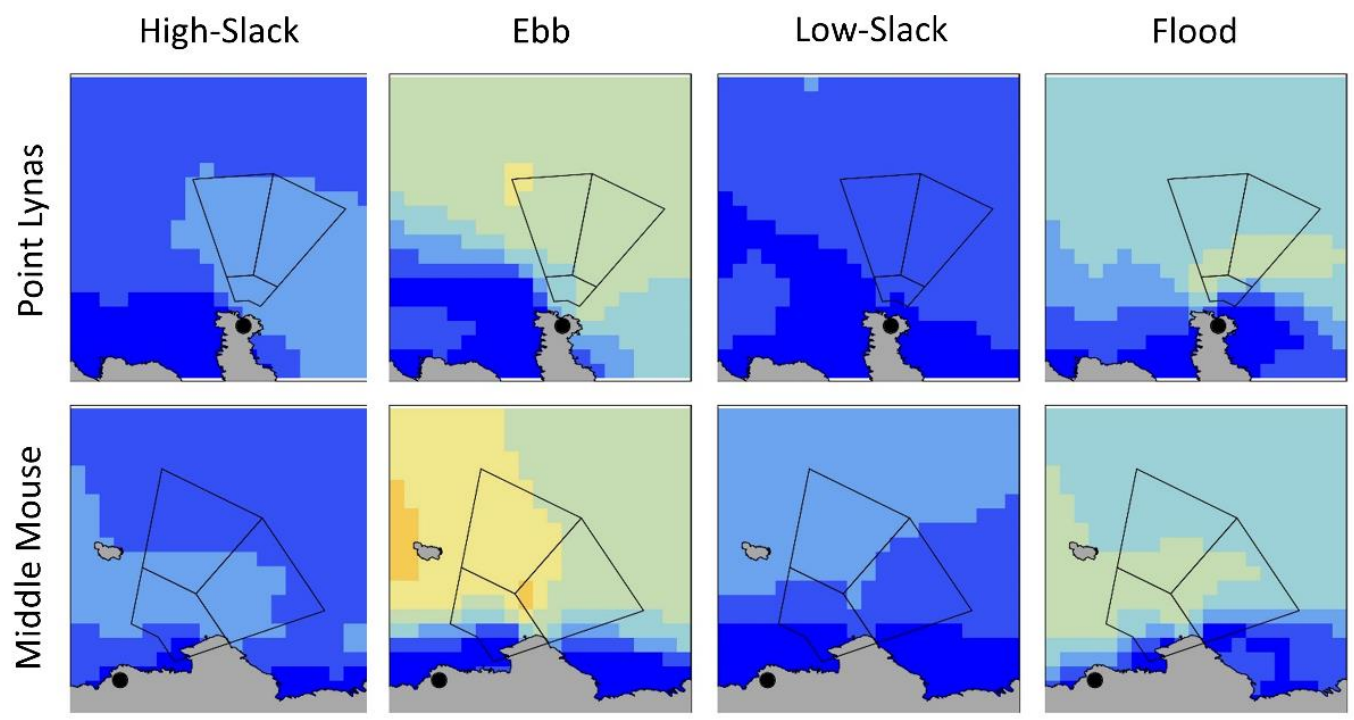

$\mathrm{ms}^{-1}$
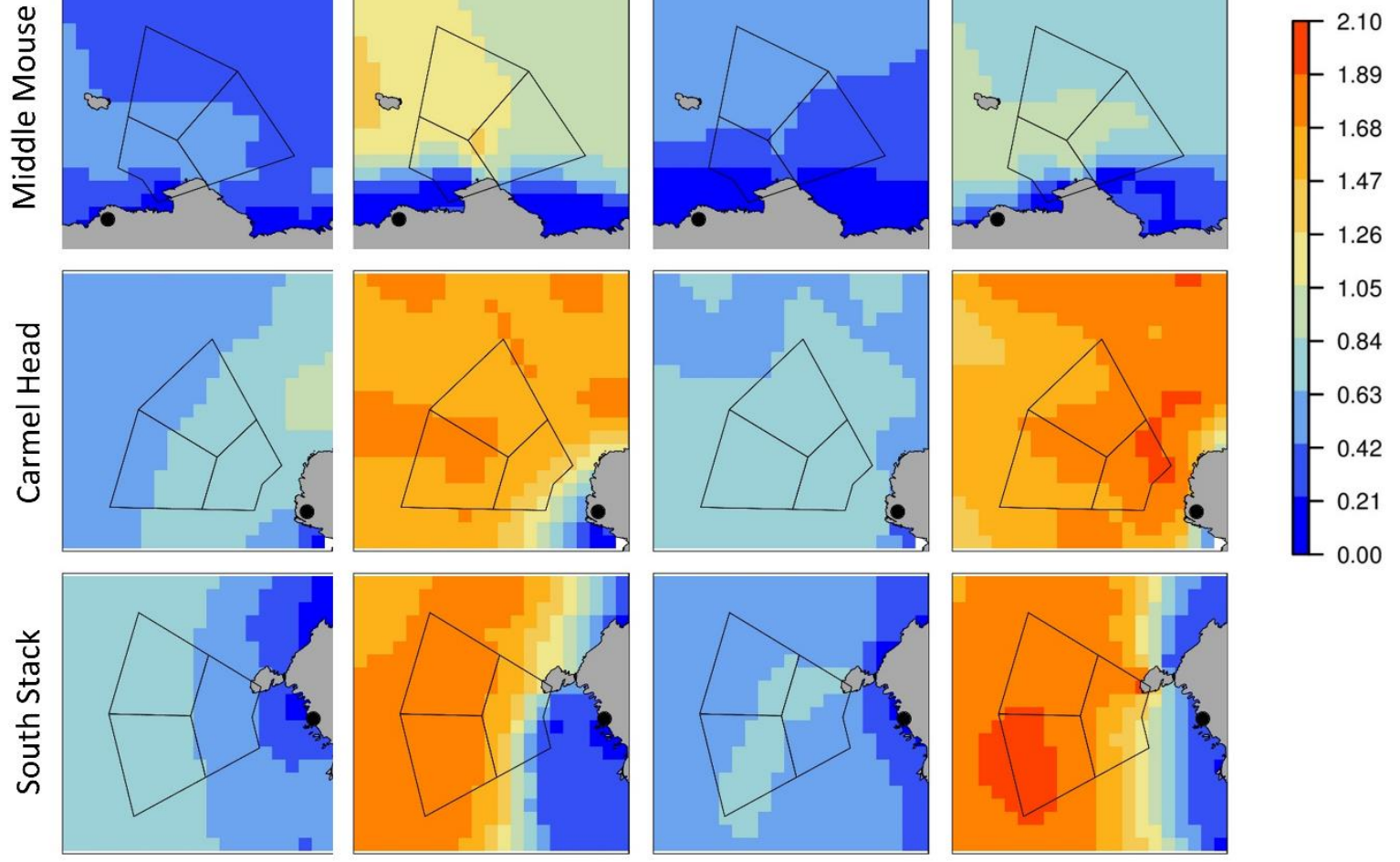

Figure 3: Spatial variation in mean current speeds $\left(S p d: \mathrm{ms}^{-1}\right)$, averaged per tidal state and site, between the $10^{\text {th }}$ and $24^{\text {th }}$ June 2016 in Anglesey, U.K. Values were sourced from simulation models. Also shown are the zones used to divide and quantify observation effort during shorebased surveys of harbour porpoise. The black point indicates the location of the vantage point used in these surveys. 


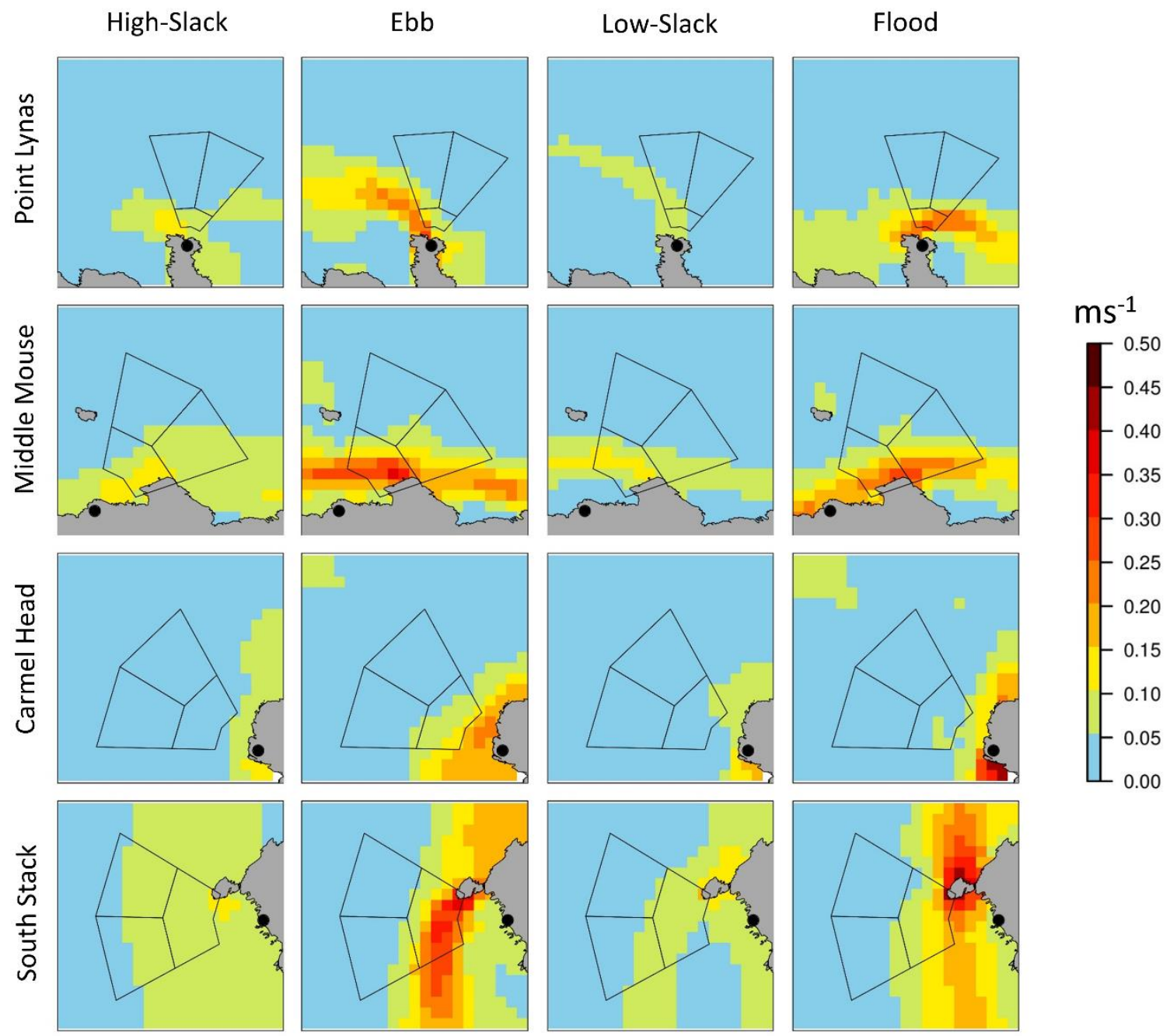

Figure 4: Spatial variation in mean current speed gradients $\left(S p d G: \mathrm{ms}^{-1}\right)$, averaged per tidal state and site, between the $10^{\text {th }}$ and $24^{\text {th }}$ June 2016 in Anglesey, U.K. Values were sourced from simulation models. Also shown are the zones used to divide and quantify observation effort during shore-based surveys of harbour porpoise. The black point indicates the location of the vantage point used in these surveys. 
Point Lynas

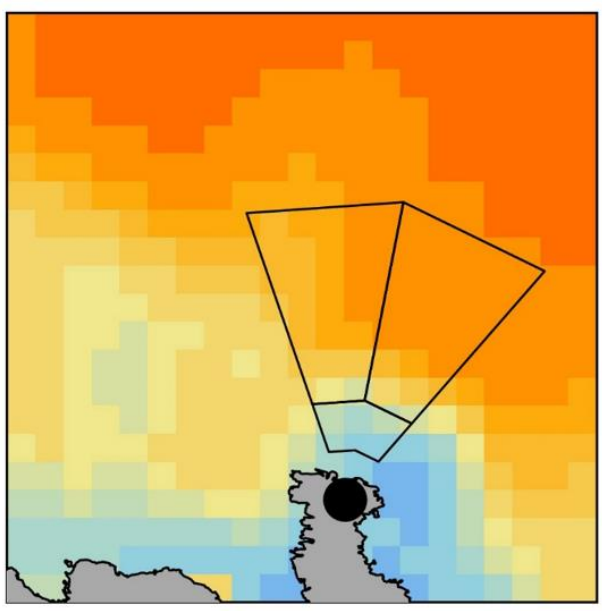

Carmel Head

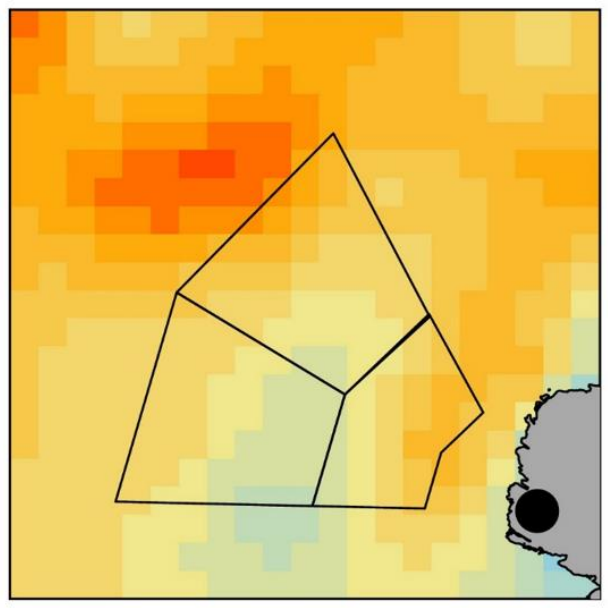

Middle Mouse

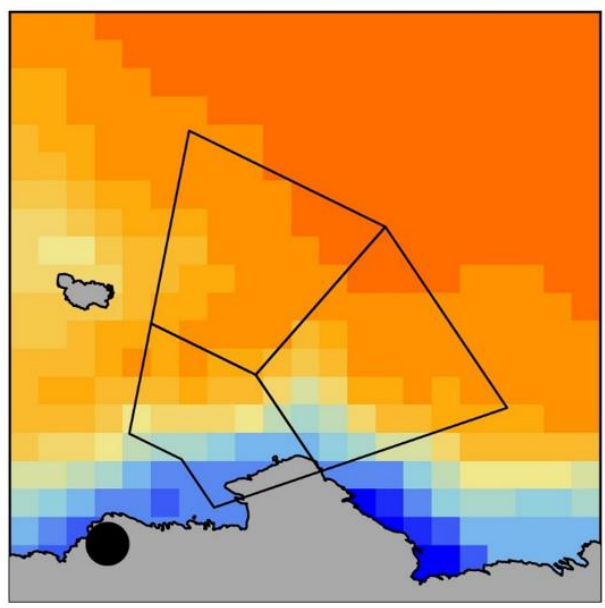

South Stack

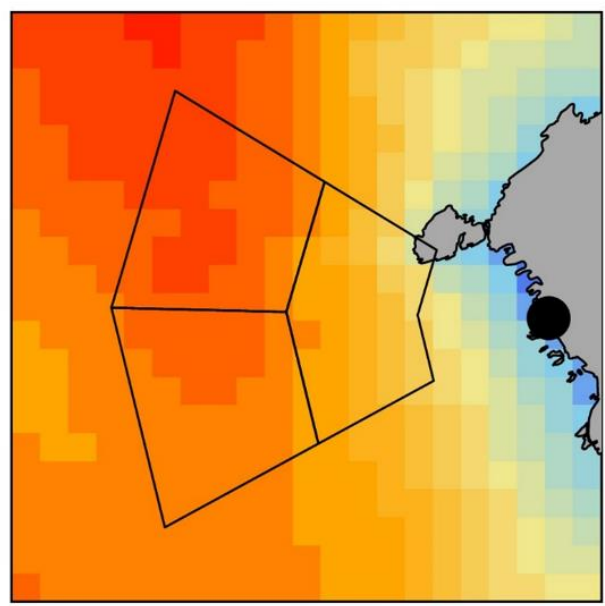

$\mathrm{m}$

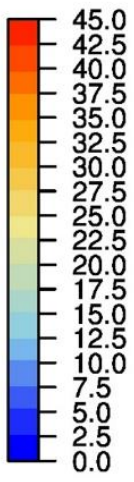

Figure 5: Spatial variation in mean water depth (Depth: $\mathrm{m}$ ), averaged per site, between the $10^{\text {th }}$ and $24^{\text {th }}$ June 2016 in Anglesey, U.K. Values were sourced from simulation models. Also shown are the zones used to divide and quantify observation effort during shore-based surveys of harbour porpoise. The black point indicates the location of the vantage point used in these surveys. 

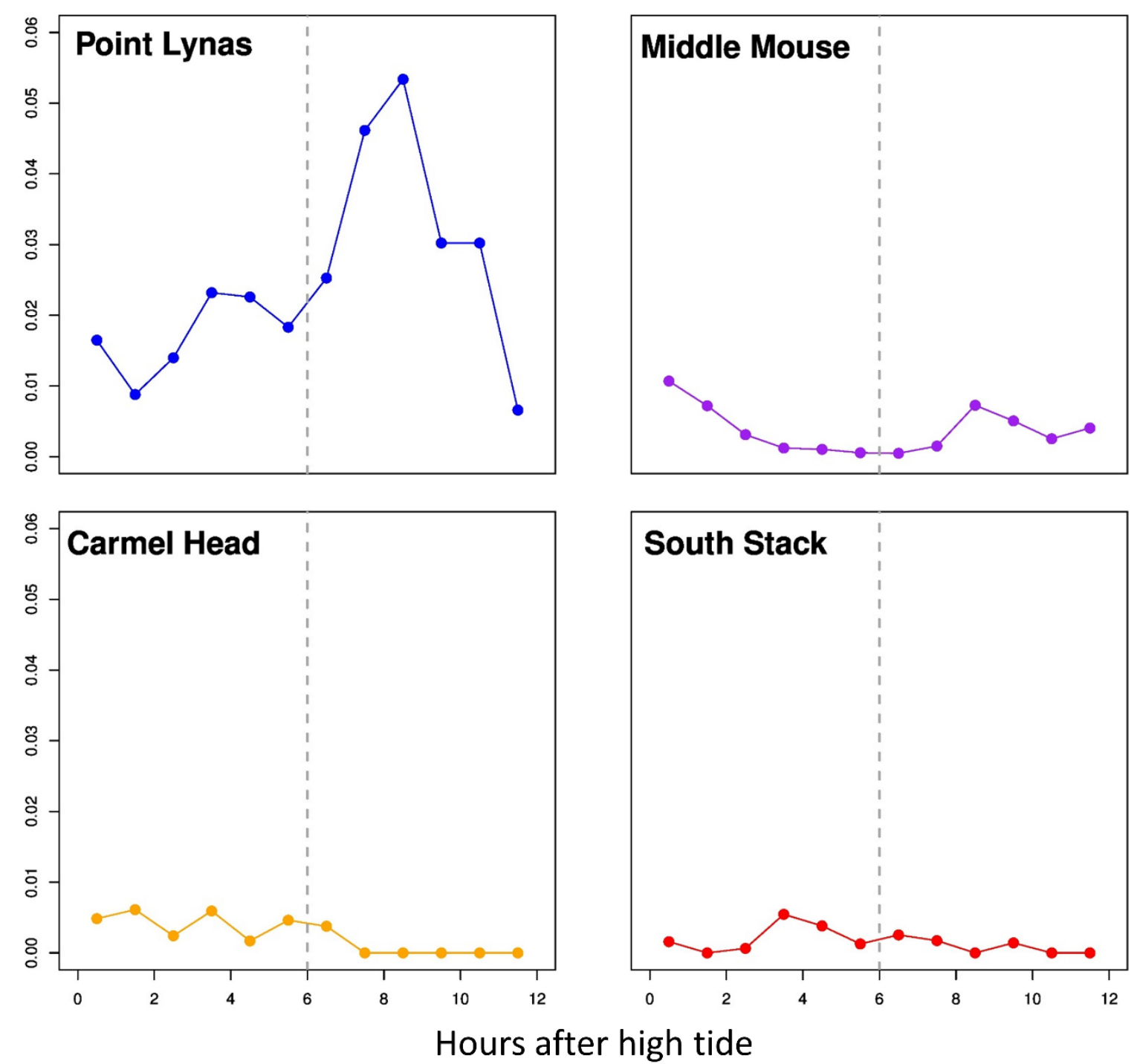

Figure 6: Temporal variation (across the diurnal tidal cycle) in the probability of detecting a harbour porpoise Phocoena phocoena in a cell between the $10^{\text {th }}$ and $24^{\text {th }}$ June 2016 within Anglesey, U.K. Cells are $100 \mathrm{~m}$ x $100 \mathrm{~m}$ resolution. The dashed grey line indicates the time of low tide. 


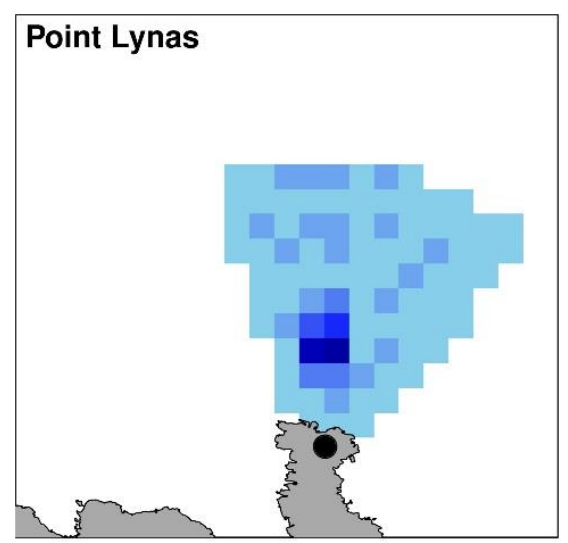

Carmel Head

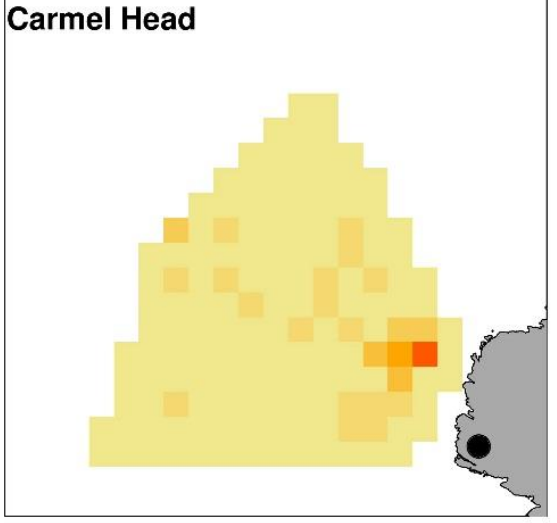

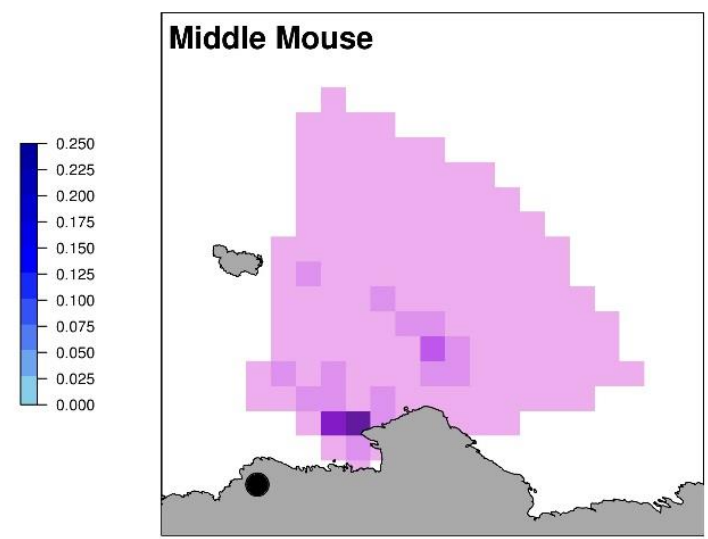
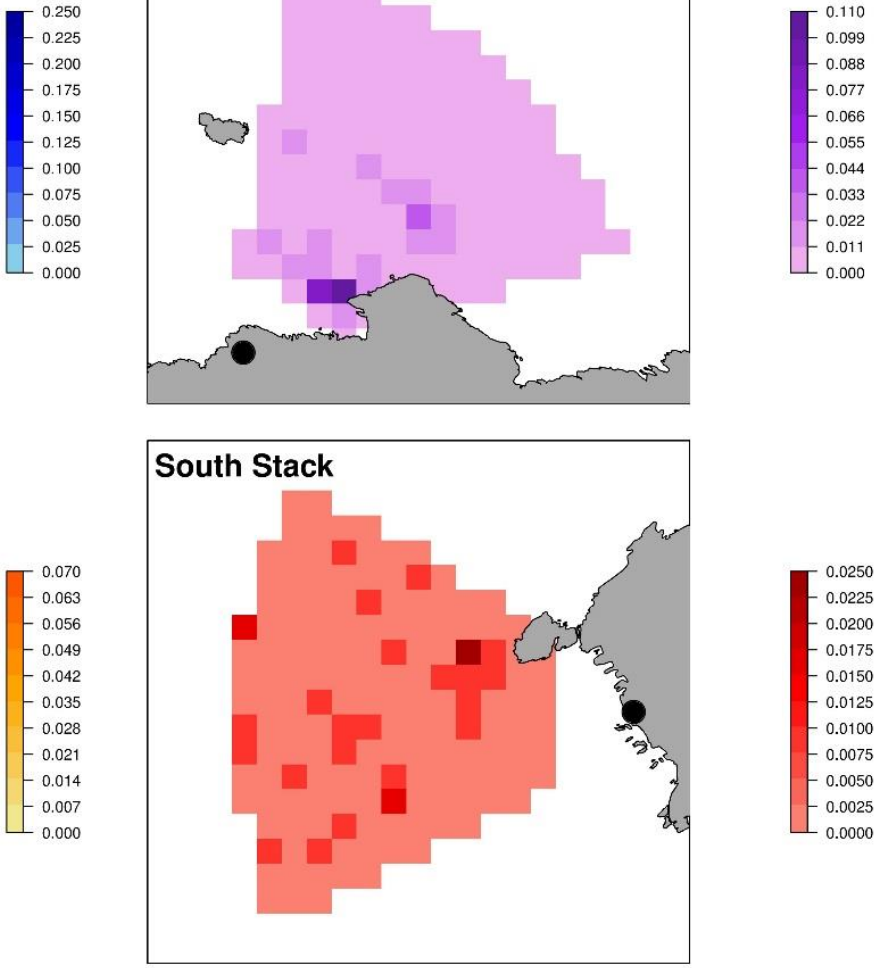

Figure 7: Spatial variation in the probability of detecting a harbour porpoise Phocoena phocoena in a cell between the $10^{\text {th }}$ and $24^{\text {th }}$ June 2016 within Anglesey, U.K. Cells are $100 \mathrm{~m}$ $\mathrm{x} 100 \mathrm{~m}$ resolution. The black point indicates the location of the vantage point used in shorebased surveys. 

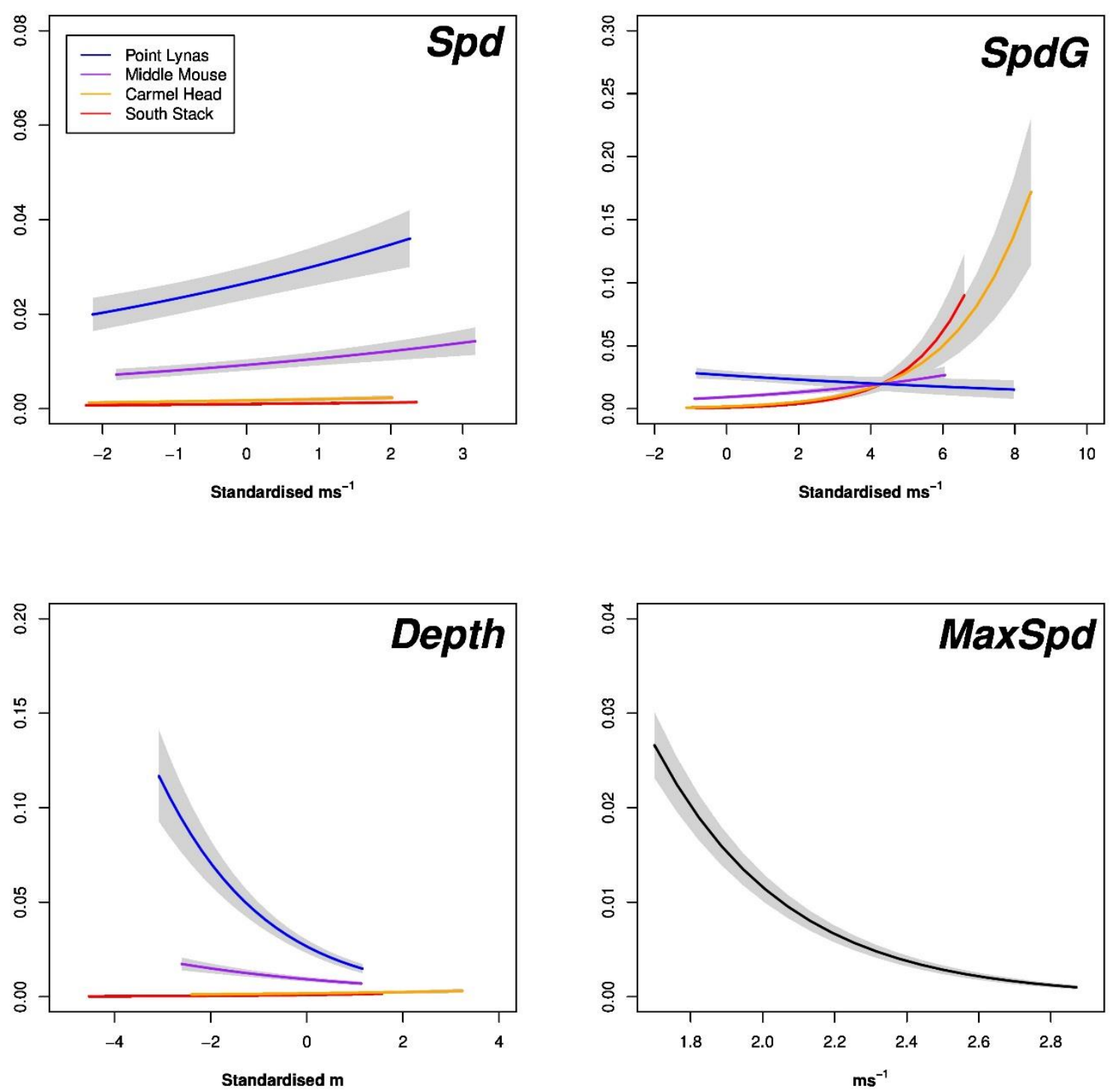

Figure 8: The modelled probability of detecting a harbour porpoise Phocoena phocoena in a cell as a function of simulated hydrodynamic characteristics (Spd: current speed, SpdG: current speed gradient, Depth: water depth; MaxSpd: maximum current speed) within Anglesey, U.K. Hydrodynamic characteristics were standardised per site by mean centring values. Cells are $100 \mathrm{~m}$ × $100 \mathrm{~m}$ resolution. Relationships were quantified using generalized linear models (GLM) with a binomial distribution. 
